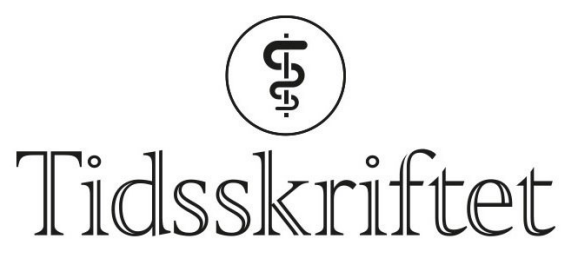

DEN NORSKE LEGEFORENING

\title{
Mekanisk eller biologisk hjerteklaffprotese?
}

FRA ANDRE TIDSSKRIFTER

JON MAGNUS HAGA

Tidsskriftet

Pasienter med mekanisk klaffeprotese lever lenger enn dem med biologisk klaffeprotese, viser en ny studie fra USA.

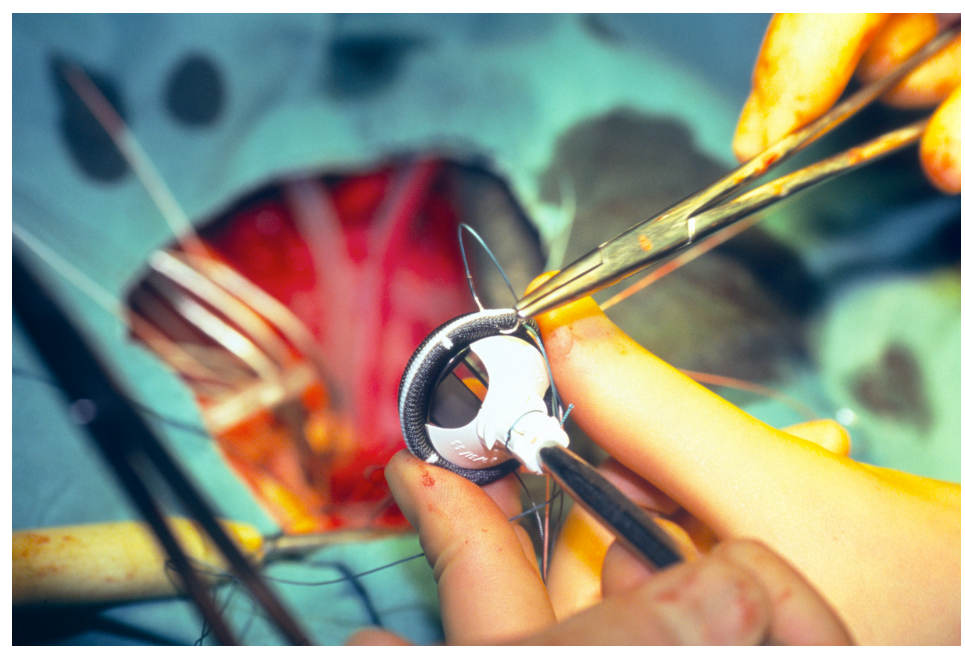

Festing av kunstig hjerteklaff. Illustrasjonsfoto: Science Photo Library/NTB scanpix

Hjerteklaffer som lekker eller er trange, må noen ganger byttes ut. Valget står mellom en mekanisk eller en biologisk klaffeprotese. I en registerstudie som nylig er publisert i New England Journal of Medicine, unders $\emptyset$ kte man langtidsoverlevelse hos om lag 25 ooo pasienter som hadde fått byttet ut sin aortaklaff eller mitralklaff i perioden 1996-2013 (1).

Mekanisk klaffeprotese hadde lavest dødelighet i de fleste aldersgruppene. Hos de eldste pasientene var det ingen forskjell. Farlige blødningskomplikasjoner var vanligere hos pasienter med mekanisk klaffeprotese, mens pasienter med biologisk klaffeprotese oftere måtte reopereres.

- Valget mellom biologisk eller mekanisk hjerteklaffprotese har gjerne vært styrt av alder og eventuelle kontraindikasjoner mot antikoagulasjonsbehandling, sier Rune Wiseth, som er professor i hjertemedisin ved Norges teknisk-naturvitenskapelige universitet.

Retningslinjene for valg av protesetype har imidlertid et svakt evidensgrunnlag. Det er noe av bakgrunnen for denne studien, sier han.

- Gruppene som ble sammenlignet er i utgangspunktet nokså forskjellige både hva gjelder 
alder og komorbiditet, så selv etter bruk av avanserte statistiske metoder kan man ikke utelukke en viss restkonfundering, sier Wiseth, som mener det er usikkert hvor mye nytt denne studien tilfører ved vurderingen av enkeltpasienter.

LITTERATUR:

1. Goldstone AB, Chiu P, Baiocchi M et al. Mechanical or Biologic Prostheses for Aortic-Valve and Mitral-Valve Replacement. N Engl J Med 2017; 377: 1847 - 57. [PubMed][CrossRef]

Publisert: 19. februar 2018. Tidsskr Nor Legeforen. DOI: 10.4045/tidsskr.17.1105

(C) Tidsskrift for Den norske legeforening 2020. Lastet ned fra tidsskriftet.no 